International Journal of Current Advanced Research

ISSN: O: 2319-6475, ISSN: P: 2319 - 6505, Impact Factor: SJIF: 5.995

Available Online at www.journalijcar.org

Volume 6; Issue 3; March 2017; Page No. 2798-2802

DOI: http://dx.doi.org/10.24327/ijcar.2017.2802.0108

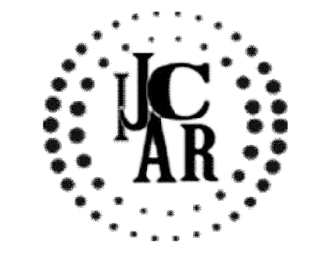

Research Article

\title{
HEPATIC JAUNDICE - A REVIEW
}

\author{
*M.R Mugilan., V.Vishnu Priya and R.Gayathri
}

Department of Biochemistry Saveetha Dental College \& Hospitals Chennai-600 077

\section{A R T I C L E I N F O}

\section{Article History:}

Received $18^{\text {th }}$ December, 2016

Received in revised form $16^{\text {th }}$ January, 2017

Accepted $26^{\text {th }}$ February, 2017

Published online $28^{\text {th }}$ March, 2017

Key words:

Perturbed differential equations, delay,

collocation method, Finite Element Method.

\begin{abstract}
A B S T R A C T
Aim : To do review on hepatic jaundice

Objective : To create an awareness and causes of hepatic jaundice

Background : Hepatocellular (hepatic) jaundice can be caused by acute or chronic hepatitis, hepatotoxicity, cirrhosis. Hepatic jaundice if not treated properly may cause permanent damage to liver. Thus an awareness on causes and prevention of hepatic jaundice is very essential.
\end{abstract}

Copyright $\bigcirc 2017$ M.R Mugilan., V.Vishnu Priya and R.Gayathri. This is an open access article distributed under the Creative Commons Attribution License, which permits unrestricted use, distribution, and reproduction in any medium, provided the original work is properly cited.

\section{INTRODUCTION}

Jaundice, also known as icterus, is a yellowish or greenish pigmentation of the skin and whites of the eyes due to high bilirubin levels.[1][2] It is commonly associated with itchiness.[3] The feces may be pale and the urine dark.[4] Jaundice in babies occurs in over half in the first week following birth and in most is not a problem.[1][2] If bilirubin levels in babies are very high for too long a type of brain damage, known as kernicterus, may occur.[5]Causes of jaundice vary from non-serious to potentially fatal.[6] Levels of bilirubin in blood are normally below $1.0 \mathrm{mg} / \mathrm{dL}$ (17 $\mu \mathrm{mol} / \mathrm{L})$ and levels over $2-3 \mathrm{mg} / \mathrm{dL}(34-51 \mu \mathrm{mol} / \mathrm{L})$ typically results in jaundice.[7][4] High bilirubin is divided into two types: unconjugated (indirect) and conjugated (direct).[8] Conjugated bilirubin can be confirmed by finding bilirubin in the urine.[9] Other conditions that can cause yellowish skin but are not jaundice include carotenemia from eating large amounts of certain foods and medications like rifampin.[4] High unconjugated bilirubin may be due to excess red blood cell breakdown, large bruises, genetic conditions such as Gilbert's syndrome, no eating for a prolonged period of time, newborn jaundice, or thyroid problems.[4][6] High conjugated bilirubin may be due to liver diseases such as cirrhosis or hepatitis, infections, medications, or blockage of the bile duct.[4] In the developed world the cause is more often blockage of the bile duct or medications while in the

*Corresponding author: M.R Mugilan

Department of Biochemistry Saveetha Dental College \& Hospitals Chennai-600 077 developing world it is more often infections such as viral hepatitis, leptospirosis, schistosomiasis, or malaria.[4] Blockage of the bile duct may occur due to gallstones, cancer, or pancreatitis.[4] Medical imaging such as ultrasound is useful for detecting bile duct blockage.[9]Treatment of jaundice is typically determined by the underlying cause.[10] If a bile duct blockage is present surgery is typically required, otherwise management is medical.[10] Medical management may involve treating infectious causes and stopping medication that could be contributing.[10] Among newborns, depending on age and prematurity, a bilirubin greater than 4$21 \mathrm{mg} / \mathrm{dL}(68-360 \mu \mathrm{mol} / \mathrm{L})$ may be treated with phototherapy or exchanged transfusion.[7] The itchiness may be helped by draining the gallbladder or ursodeoxycholic acid.[3] The word jaundice is from the French jaunisse, meaning "yellow disease".[11]

Types

On the basis of causes Jaundice can be classified into three types. 4

$>$ Pre-hepatic Jaundice

$>$ Hepatic Jaundice

$>$ Post hepatic Jaundice

$>$ Pre-hepatic Jaundice

Pre hepatic jaundice is such type of jaundice which is caused due to hemolysis therefore it is also known as hemolytic jaundice. The major cause of enhanced hemolysis is defective plasma membrane of red blood cells. This vulnerable cell membrane cannot bear the shear stress and hence ruptures resulting in hemolysis thus causing the increased serum bilirubin level.16,17 


\section{Etiology}

The pre hepatic jaundice is mainly caused due to hemolysis. The causes of pre-hepatic/hemolytic jaundice are classified into two groups:

\section{Congenital causes}

Congenital causes of hepatic jaundice involve following:19,20

- Spherocytosis

- Elliptocytosis

- Congenital LCAT deficiency • Thalassemia

- Sickle cell anemia

- Stomatocytosis

- Acanthocytosis

- Echinocytes

- GSH synthase deficiency

- Pyruvate kinase deficiency

- G6PD deficiency

- Erythroblastosis fetalis

Acquired causes

Acquired causes of pre-hepatic jaundice involve following:19, 20

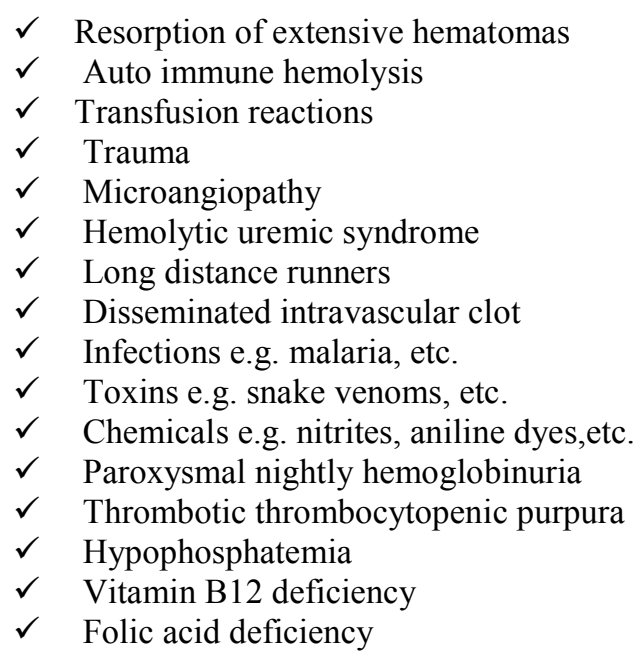

\section{Clinical presentations}

Patients with hemolytic jaundice are presented with Anemia, Yellowing of sclera, dark yellow-brown colored urine, yellowish skin and high bilirubin levels.21

\section{Hepatic jaundice}

Hepatic jaundice is a type of jaundice in which the basic defect lies within the liver mainly in the hepatocytes. The liver captures bilirubin from plasma proteins mainly albumin, then after conjugation excretes in the bile via biliary system. Any pathology of the liver leading to defect in capture, conjugation and excretion can cause hepatic jaundice. Main enzyme of conjugation is UDP- Glucronyltransferase. This is commonly immature at birth and its under-activity can cause so called Neonatal Physiological Jaundice. Further this enzyme can be defective due to the genetic mutation of the UTG1A gene. on chromosome 2. This gene encodes for UDP- Glucronyltransferase and thus the defective conjugating enzyme leads to the hepatic jaundice.22-24 Any defect in the hepatic excretory mechanism of bilirubin can also cause hepatic jaundice. The excretory mechanisms involve hepatocytic bile acid-independent secretion, hepatocytic bile acid-dependent secretion and bile ductular secretion. Any defect in the above mentioned excretory mechanisms can lead to the accumulation of bilirubin in blood causing hepatic jaundice.25-34.

\section{Etiology}

Hepatic jaundice is caused due to the defect in capture, conjugation and excretion of bilirubin by liver.35-38 Hepatic causes of the jaundice can be classified in to two types:

\section{Congenital causes}

\section{Congenital causes of hepatic jaundice are following:38,39}

- Wilson's Disease

- Rotor's Syndrome

- Haemochromatosis

- CriglerNajar syndrome

- Gilbert's syndrome

- Dubin-Johnson's syndrome

\section{Acquired causes}

Acquired causes of hepatic jaundice are following:38,39

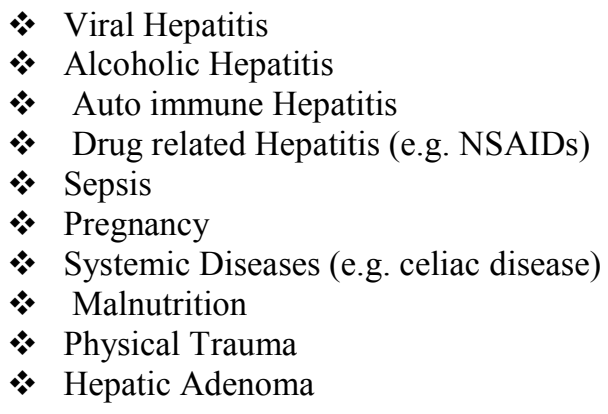

\section{Clinical presentations}

The clinical presentations of hepatic jaundice include abdominal pain, fever, vomiting and nausea along with the complications involving satiety, gastrointestinal bleeding, diarrhea, anemia, edema, weight-loss and associated weakness, if unchecked leading to mental disturbances like kernicterus, coma or even death. 40

\section{Post hepatic jaundice}

Post hepatic jaundice is such type of a jaundice in which the cause lies in the biliary portion of hepatobiliary system. The major cause of post hepatic jaundice is extra- hepatic biliary obstruction. Therefore it is also Known as obstructive jaundice. 41

\section{Etiology}

The major cause of post hepatic jaundice is extra-hepatic biliary obstruction.41 The causes of obstruction may be classified into two types:

\section{Congenital causes}

The congenital obstruction involves following:41,42

- Biliary Atresia

- Cystic Fibrosis

- Idiopathic dilation of common bile duct • Pancreatic biliary malfunction

- Choledochal Cyst 


\section{Acquired Causes}

The acquired obstruction involves following:42

- Portal biliopathy $\bullet$ Cholecystitis

- Trauma

- Pancreatitis

- Strictures

- Choledocholithiasis

- AIDS

- Intra-Abdominal Tuberculosis • Tumors

- Common bile duct Obstruction

\section{Clinical presentation}

The clinical manifestations of obstructive jaundice are dark urine, pale stools and generalized pruritus. History of fever biliary colic, weight loss, abdominal pain and abdominal mass are also the representatives of obstructive jaundice.42 Obstructive Jaundice may lead to various complications including cholangitis, pancreatitis, renal and hepatic failure.

\section{DISCUSSION}

\section{Differntial diagnosis}

The pre-hepatic jaundice can be differentiated from hepatic and post hepatic jaundice exclusively on the basis of elevated serum levels of unconjugated bilirubin and urobilinogen, which are raised in case of pre-hepatic jaundice. The serum levels on conjugated bilirubin, alkaline phosphatase, Alanine transferase and Aspartate transferase are seen normal in the case of pre-hepatic jaundice. The urinary excretion of conjugated bilirubin is also not present in pre-hepatic jaundice.50 The hepatic jaundice can be differentiated from post hepatic and pre hepatic jaundice on the basis of five times high bilirubin levels. In hepatic jaundice due to hepatitis the bilirubin levels may be ten times higher than their maximum values.38, Hepatic jaundice can be differentially diagnosed from post hepatic jaundice on the basis of abdominal ultrasonography and other radiological technique.38 However the hepatic jaundice can be differentiated from pre-hepatic jaundice on the basis of diagnostic markers, like alpha-1 Antitrypsin, Ceruloplasmin, Immunoglobulins,etc.35,38,39, Elevated serum bilirubin level along with the conjugation is a key diagnosis of post hepatic jaundice. Serum bilirubin is usually less than $20 \mathrm{mg} / \mathrm{dL}$. In pancreatic cancer the serum bilirubin may rise up to 40 $\mathrm{mg} / \mathrm{dL}$. Serum gamaglutamyltranspeptidase (Serum GGT), alkaline phosphatase and transaminases may be elevated. Tumour markers like CA-125, CA19-9 and CEA are usually elevated in cancerous obstruction. 42 The diagnosis of obstructive jaundice can further be confirmed by ultrasonography, plain abdominal x-ray, computed tomography, contrast-enhanced multi sliced computed tomography, endoscopic retrograde cholangiopancreatography (ERCP), Percutaneous transhepatic cholangiography (PTC), Endoscopic Ultrasound, Magnetic Resonance cholangiopancreatography (MRCP),Cholescintigraphy, Radionuclide scanning angiography and Staging Laparoscopy.4,43,44

\section{Therapeutic approaches and managements}

\section{Pre hepatic jaundice}

Infusion of immunoglobulins is used as primary treatment for pre-hepatic jaundice. Phototherapy is considered as an effective treatment of high levels of bilirubin in pre-hepatic jaundice. Bilirubin rapidly decreases within two hours of onset of phototherapy.However the duration of therapy and the strength of light treatment depend upon the severity of hyperbilirubinemia.Metaloporphyrins are also considered as a treatment possibility of pre-hepatic jaundice, because these metaloporphyrins target the hemeoxygenase enzyme to limit the production of bilirubin.

\section{Hepatic jaundice}

\section{Treatment and Management of hepatic jaundice involves}

- Phototherapy - for neonatal jaundice.

- Phenobarbital can be used for treatment of neonatal physiological jaundice however it is not frequently used due to certain drawbacks involving somnolence and febrile seizures.

- Supportive therapy - fluids, rest, pain relief - for Hepatitis A.

- Abstinence from alcohol and cessation of medications contributing to liver dysfunction.

- Steroids - for autoimmune hepatitis.

- Immunosuppressant - for autoimmune hepatitis.

- Interferon - for chronic hepatitis B and C.

- Liver transplantation for fulminant hepatitis and end stage liver failure.

\section{Post hepatic jaundice}

Low fat diet should be given to patient suffering from posthepatic jaundice to minimize the discomfort due to fat ingestion and diarrhea.35, The treatment of the post hepatic obstructive jaundice is mechanical decompression however the complications and other symptoms are also necessarily treated. Decompression can be done by surgical bypass, percutaneous insertion of stents, removal of lesions and endoscopic insertion of stents.45 Dexchlorophenramine, Hydroxyzine, Cholestyramine, Ursodeoxycholic acid and Naltrexone are used as a therapeutic approach in treatment and management of post hepatic jaundice.35,

\section{CONCLUSION}

Jaundice is very common disease. Yellowing of skin, sclera and mucous membranes are common manifestations of jaundice due to defect in production, metabolism and excretion of bilirubin. The causes of jaundice are either congenital or acquired. Serum bilirubin level and ultrasonography are used for differential diagnosis. High water intake and low fat diet are best proper managements of jaundice. The treatment of jaundice varies with the type of jaundice.

\section{Reference}

1. Roche SP, Kobos R. Jaundice in the adult patient. Am Fam Physician. 2004;69(2):299-304.

2. Tiribelli C, Ostrow JD. The molecular basis of bilirubin encephalopathy and toxicity: report of an EASL single topic conference. $J$ Hepatol. 2005;43:156-6.

3. Blanckaert N, Heirwegh KP, Compernolle F. Synthesis andseparation by thin-layer chromatography of bilirubin-IX isomers. Their 
identification as tetrapyrroles and dipyrrolic ethyl anthranilate azo derivatives. Biochem J. 1976;155 (2):405-17.

4. Briggs $\mathrm{CD}, \mathrm{M}$ Peterson. Investigation and management of obstructive jaundice. Surgery. 2007;25(2):74-80.

5. Drummond GS, Kappas A. Chemoprevention of severeneonatal hyperbilirubinemia. SeminPerinatol. 2004;28:365-8.

6. Roche SP, Kobos R. Jaundice in the adult patient. Am Fam Physician. 2004;69(2):299-304.

7. Kamisako T, Kobayashi Y, Takeuchi K, Ishihara T, Higuchi K, Tanaka Y. Recent advances in bilirubin metabolism research: the molecular mechanism of hepatocyte bilirubin transport and its clinical relevance. J Gastroenterol. 2000;35(9):659-64.

8. Berk PD, Howe RB, Bloomer JR, Berlin NI. Studies of bilirubin kinetics in normal adults. $J$ Clin Invest. 1969;48:2176-90.

9. Brodersen R. Bilirubin, Solubility and interaction with albumin and phospholipid. $J$ Biol Chem. 1979;254:2364-9.

10. Muraca M, Fevery J. Influence of sex and sex steroids on bilirubin uridine diphosphateglucuronosyltransferase activity of rat liver. Gastroenterology. 1984;87:308-13.

11. Black M, Fevery J, Parker D, Jacobson J, Billing $\mathrm{BH}$, Carson ER. Effect of phenobarbitone on plasma (14C) bilirubin clearance in patients withunconjugated hyperbilirubinaemia. ClinSciMol Med. 1974;46:1-17.

12. Lankisch TO, Moebius U, Wehmeier M, Behrens G, Manns MP, Schmidt RE, et al. Gilbert's disease and atazanavir: from phenotype to UDP glucuronosyltransferase haplotype. Hepatology. 2006;44:1324-32.

13. Van Steenbergen W, Fevery J, De Groote J. Thyroid hormones and the hepatic handling of bilirubin II. Effects of hypothyroidism and hyperthyroidism on the apparent maximal biliary secretion of bilirubin in the Wistar rat. J Hepatol. 1988;7:229-38.

14. Van Steenbergen W, Fevery J. Effects of uridine diphosphate glucuronosyl transferase activity on the maximal secretion rate of bilirubin conjugates in the rat. Gastroenterology. 1990;99:488-99.

15. Maitra A. Pancreas. In: Vinay Kumar, Abul K. Abbas, Jon C Aster. Robbins Basic Pathology. 9th ed. Philadelphia, PA: Elsevier. 2013; 645-656.

16. Wickramasinghe SN, Wood WG. Advances in the understanding of the dyserythropoieticanaemias. $\mathrm{Br}$ $J$ 2005;131:431-46.congenital Haematol.

17. Glader B. Anemia: general consideration. In: Greer JP, eds. Wintrobe's Clinical Hematology. Chapter 27. Lippincott, Williams \& Wilkins Co; 2004:96575.

18. Jacques G. Types of jaundices. Visual Understanding Environment (VUE). Enigma. 2009;18:55.

19. Galanello R, Piras S, Barella S, Leoni GB, Cipollina MD, Perseu L. Cholelithiasis and Gilbert's syndrome in homozygous $\mathrm{b}$ thalassaemia. $\mathrm{Br} J$ Haematol. 2001;115:926-8.
20.

Bosma PJ, Chowdhury NR, Goldhoorn BG et al. Sequence of exons and the flanking regions of human bilirubin-UDP - glucuronosyltransferase gene complex and identification of a genetic mutation in a patient with Crigler-Najjar syndrome, type I. Hepatology. 1992;15:941-7.

21. Bektaş M, Dökmeci A, Cinar K, Halici I, Oztas E, Karayalcin S. Endoscopic management of biliary parasitic diseases. Dig Dis Sci. 2010;55(5):1472-8.

22. Raijmakers MT, Jansen PL, Steegers EA, Peters WH. Association of human liver bilirubin UDPglucuronyltransferase activity with a polymorphism in the promoter region of the UGT1A1 gene. $J$ Hepatol. 2000;33:348-51.

23. Persico M, Persico E, Bakker CT, Rigato I, Amoroso A, Torella R. Hepatic uptake of organic anions affects the plasma bilirubin level in subjects with Gilbert's syndrome mutations in UGT1A1. Hepatology. 2001;33(3):627-32.

24. Ostanek B, Furlan D, Mavec T, Lukac-Bajalo J. UGT1A1 (TA)n promoter polymorphism-a new case of a (TA) 8 allele in Caucasians. Blood Cells Mol Dis. 2007;38(2):78-82.

25. Dumont M, D'Hont C, Lamri Y, Durand-Schneider AM, Jacquemin E, Feldmann G. Effects of phalloidin and colchicine on diethylmaleate-induced choleresis and ultrastructural appearance of rat hepatocytes. Liver. 1994;14(6):308-13.

26. Pauli-Magnus C, Stieger B, Meier Y, Kullak-Ublick GA, Meier PJ. Enterohepatic transport of bile salts and genetics of cholestasis. J Hepatol. 2005; 43:342-

57.

27. Pauli-Magnus C, Meier PJ. Hepatobiliary transporters and drug-induced cholestasis. Hepatology. 2006;44:778-87.

Geier A, Wagner M, Dietrich CG, Trauner M.

28. Principles of hepatic organic anion transporter regulation during cholestasis, inflammation and liver regeneration. Biochim Biophys Acta. 2007; 1773:283-308

29. Kaplan MM, Righetti A. Induction of rat liver alkaline phosphatase: the mechanism of the serum elevation in bile duct obstruction. $J$ Clin Invest.1970;49:508-16.

30. Blanckaert N, Compernolle F, Leroy P, Van Houtte R, FeveryJ, Heirwegh KP. The fate of bilirubinIXalphaglucuronidein cholestasis and during storage in vitro. Intramolecular rearrangement to positional isomers of glucuronic acid. Biochem $J$. 1978;171:203-14.

31. Van Hootegem P, Fevery J, Blanckaert N. Serum bilirubins in hepatobiliary disease: comparison with other liver function tests and changes in the postobstructive period. Hepatology.1985;5:112-7.

32. Billing $\mathrm{BH}$. Intestinal and enal metabolism of bilirubin, including enterohepatic circulation. In: Donald Ostrow J, ed. Bile Pigments and Jaundice. New York: Marcel Dekker Inc; 1986:255-70.

33. Fulop M, Katz S, Lawrence C. Extreme hyperbilirubinemia. Arch Intern Med. 1971;127:254-8. 
34. Medley MM, Hooker RL, Rabinowitz S, Holton R, Jaffe BM. Correction of congenital indirect hyperbilirubinemia by small intestinal transplantation. Am J Surg. 1995;169:20-7.

35. Lidofsky SD, Kobos R. Jaundice. In: Sleisenger and Fordtrant's Gastrointestinal and Liver Disease. 8ed. Philadelphia, Saunders Elsevier; 2006:301-16.

36. Beckingham IJ, Ryder SD. ABC of diseases of the liver, pancreas and biliary system: investigation of liver and biliary disease. BMJ. 2001;322:33-6.

37. Ryder SD, Beckingham IJ. ABC of diseases of the liver, pancreas and biliary system: other causes of parenchymal liver disease. BMJ. 2001;322:290-2.

38. Roche SP, Kobos R: Jaundice in the adult patient. Am Fam Physician. 2004;69:299-304.

39. Merriman RB, Peters MG. Approach to the patient with jaundice. In: Yamada $\mathrm{T}$ Textbook of Gastroenterology.4ed. Philadelphia. Lippincott Williams and Wilkins; 2003:911-28.
40. Mathew KG. Medicine: Prep manual for undergraduates. 3/e. Elsevier. India; 2008:296-7.

41. Vendemiale G, Grattagliano I, Lupo L, Memeo V, Altomare E. Hepatic oxidative alterations in patients with extra-hepatic cholestasis. Effect ofsurgical drainage. J Hepatol. 2002;37(5):601-5.

42. Malhi H, Gores GJ, Malhi H, Gores GJ. Review article: the modern diagnosis and therapy of cholangiocarcinoma. Aliment Pharmacol Ther. 2006;23(9):1287-96.

43. Barkun JS, Chaudhury P, Barkun AN. Approach to the Jaundiced Patient. ACS Surgery: principles and practice. 2006.

44. Yusuf TE, Bhutani MS, Yusuf TE, Bhutani MS. Role of endoscopic ultrasonography in diseases of the extrahepatic biliary system. J Gastroenterol Hepatol. 2004;19(3):243-50.

\section{Please cite this article in press as:}

M.R Mugilan et al (2017), 'Hepatic jaundice - a review', International Journal of Current Advanced Research, 6(3), pp. 2798-2803. http://dx.doi.org/10.24327/ijcar.2017.2798.0108 